\title{
A Quantitative Examination of Factors that Influence Technology Integration in Higher Education System
}

\author{
Hicham Laabidi* \\ Teacher-trainer at CREMF, Meknés, Morocco \\ Youssouf Laabidi \\ PhD candidate Faculty of Educational Sciences, Madinat Al Irfane, Rabat, \\ Morocco. \\ (*Corresponding Author) \\ e-mail: hicham.laabidi@yahoo.com
}

\begin{abstract}
The purpose of this paper is to explore and describe the status of technology integration in Moroccan higher education system. Forty-six university English language teachers were selected from two universities: Moulay Ismail University Faculty of Arts and Humanities - Meknes and Sidi Mohamed Ben AbdellahDahr El Mahraz-Fes. The quantitative data was analysed using descriptive statistics of frequencies and percentages. The findings revealed that teachers consider Information and Communication Technology very essential in their teaching. The results also showed that computer technology is integrated in Moroccan universities at low levels. This lack of use of the new technologies in instruction and learning was attributed to several barriers including insufficient professional development, inadequate access to computer technologies, and lack of computer training to name only few.
\end{abstract}

Keywords: technology integration, higher education, computer technology, computer training. 


\section{INTRODUCTION}

Information and Communication Technology (ICT) has become a crucial section of most organisations and businesses these days (Zhang, Aikman, 2007). Computers started to be placed in schools in the early 1980s, and numerous researchers propose that ICT will be a significant segment of education for the next generation too (Bransford, Brown, \& Cocking, 2000).It is self evident that ICT has been developing very quickly in recent years and opens new directions in the area of education. In other words, the speedy growth in ICT has brought conspicuous and notable changes in the twenty-first century, and influenced the requirements of modern societies. Bransford et al. (2000) confirm that "what is now known about learning provides important guidelines for uses of technology that can help students and teachers develop the competencies needed for the twenty-first century" (p. 206).

Dawes (2001) confirms that technologies have the capacity to assist education across the curriculum and supply chances for useful communication between learners and educators in ways that have not been possible before. That is to say, ICT in education has the ability to be effective in bringing about changes in ways of teaching. However, this potential may not easily be achieved, as Dawes ( 2001) emphasizes when he states that "problems arise when teachers are expected to implement changes in what may well be adverse circumstances" (P.61). Due to the significance of ICT in society and possibly in the future of education, recognizing the likely barriers to the integration of these technologies in schools would be a valuable step in ameliorating the quality of teaching and learning. Balanskat, Blamire, and kefala (2006) discuss that although teachers seem to admit the importance of ICT in schools, obstacles proceed to be encountered during the processes of adopting these technologies.

Obviously, the barriers to the integration of ICT into teaching and learning environments have been examined in several distinctive studies. Ertmer (1999), for instance, divides the barriers into two main classes: first-order and second-order barriers. First-order barriers stand for those difficulties concerning basically various kinds of resources such as equipment, time, training and support. This means that if teachers do not have enough materials, it will be very hard if not impossible to obtain a satisfactory integration. The second-order barriers relate to teachers' underlying beliefs about teaching and learning.

It is self evident that ICT has been developing very quickly in recent years and opens new directions in the area of education. In other words, the speedy growth in ICT has brought conspicuous and notable changes in the twenty-first century, and influenced the requirements of modern societies. Bransford et al. (2000) confirm that " what is now known about learning provides important guidelines for uses of technology that can help students and teachers develop the competencies needed for the twenty-first century" (p. 206).

Dawes (2001) confirms that technologies have the capacity to assist education across the curriculum and supply chances for useful communication between learners and educators in ways that have not been possible before. That is to say, ICT in 
education has the ability to be effective in bringing about changes in ways of teaching.

The primary purpose of this paper is to obtain satisfactory understanding of how important do Moroccan university English language teachers think ICT is in their teaching. Also, it intends to examine and analyse the difficulties and obstacles faced by teachers while employing ICT equipments in their classes. Therefore, the current paper seeks to answer the following research questions:

1. How essential do Moroccan university English language teachers think ICT is in teaching?

2. What are Moroccan university English language teachers perceived barriers to the integration of ICT in teaching?

\section{LITERATURE REVIEW}

Information and Communication Technology (ICT) can play multiple roles in learning and teaching processes. Various researchers and theorists state that the use of computers can lend a hand to learners to become knowledgeable, decrease the amount of direct instruction given to them, and provide instructors with a chance to assist those students with particular needs (Iding, Crosby, \& Speitel, 2002; Shamatha, Peressini,\&Meymaris,2004; Romeo,2006). Becta (2004) suggestes that the success of the integration of ICT into education differs from curriculum to curriculum, place to place, and class to class, depending on the way in which it is applied. Bottino (2003) and Sharma ( 2003) highlight that the employment of ICT can boost performance, teaching, administration, and enhance pertinent skills in undeveloped societies. Besides, ICT can ameliorate the nature and value of education by assisting learning by doing, real time conversation, directed instruction, problem solving, information seeking and analysis, and critical thinking, as well as the ability to communicate, collaborate and learn (Yuen, Law, Wong, 2003).

Computer Technology can be defined as new multimedia technologies, including computer software, CD-ROM, the Internet, mobile phone, television, movie as well as Internet-based Project work, e-mail, chat, blogs, wikis, podcasts, and so on (Andrews, 2000). Lever-Duffy et al. (2005), state that some 'educators may take a narrower view' and predominantly 'confine educational technology (ICTs) primarily to computers, computer peripherals and related software used for teaching and learning' (p. 4-5).

The use of ICT in the classroom is very essential for providing chances for learners to function appropriately in an information age. Obviously, with the growth of new technologies, the benefits of computers may have increased step by step as well. The centre of attention however, should not be on the computer as an instrument in education, but as a useful learning tool (Bransford et al., 2000; Romeo, 2006). Bransford et al. ( 2000) state that " what is now known about learning provides important guidelines for uses of technology that can help students and teachers develop the competencies needed for the twenty-first century" (p. 206). Another way 
of expressing this point is that institutions that do not embody the employment of ICT in schools cannot really claim to get their students ready for life in the twentyfirst century.

One of the most essential gifts of ICT in the discipline of education is easy access to learning. ICT enhances the flexibility of delivery of education so that students can approach knowledge anytime and from anywhere. It can affect the way learners are taught and how they learn. Indeed, this would get the learners ready for lifelong learning as well as to ameliorate the value of learning. Individuals are recommended to access knowledge by means of ICT to keep pace with the latest advancements (Plomp, Pelgrum, \& Law, 2007). ICT can be employed to eliminate communication obstacles such as that of space and time (Lim, Chai, 2004). More precisely, teachers and learners no longer have to depend only on printed books for their educational requirements. With the Internet, a plenty of learning materials can now be accessed from anywhere at anytime of the day. Attwell and Battle (1999) investigate the connection between owning a home computer and school performance, their conclusions propose that learners who have access to a computer at home for educational aims, have advanced scores in reading and math. Becker (2000) discovers that ICT magnifies learner engagement, which guides to an addition amount of time learners to expend working outside class.

The employment of ICTs in the classroom could foster 'deep' learning and permit teachers to react better to the various requirements of different students (Lau, Sim 2008). In other words, ICT is a very significant instrument which, when employed suitably, can cultivate the move to a learner centered environment. Harris (2002) carries out case studies in three primary and three secondary schools, which concentrated on innovative pedagogical practices including ICT. Harries deduces that the advantages of ICT will be obtained "... when confident teachers are willing to explore new opportunities for changing their classroom practices by using ICT". The employment of technology will not only intensify learning conditions but also get next generation ready for coming lives and occupations (Wheeler, 2001).

A great deal of research has demonstrated the advantages to the value of education (Al-Ansari,2006). Pelgrum (2001) has observed that ICT is "not only the backbone of the Information Age, but also an important catalyst and tool for inducing educational reforms that change our students into productive knowledge workers" (p. 2). ICT is a very powerful instrument for supplying educational chances. It is very hard, if not impossible, to picture future learning conditions that are not assisted, in one way or another, by ICT. According to Bransford et al.(2000), ICTs can be employed to assist pedagogic practices that give valuable learning environments, if they are used in suitable ways. They can operate as 'scaffolds and tools' to aid flourish learning and teaching environments (Bransford et al., 2000).

ICT displays a wholly contemporary learning environment for learners, in this way necessitating a distinctive skill set to be successful. Numerous theorists have discussed that new technologies can support students to make use of their contemporary knowledge to build new knowledge and that is an essential factor in an efficacious learning conditions (Bransford et al., 2000; Jonassen, Peck, \& Wilson, 
1999; Romeo, 2006). According to Wozney et al. (2006), teachers who favour learner-centred methods, are more likely to integrate technologies in teaching. To put the idea that has just been stated into distinctive words, since learner-centred environments presume that learners are stimulated to become responsible for their own learning (Bransford et al., 2000; Jonassen, Peck, \& Wilson, 1999), new technologies may provide students with a chance to select the manners of their learning.

ICT is possibly a strong and an effective instrument for presenting educational opportunities. Many teachers employ ICT in their classes to boost their students' motivation. The utilization of ICT in education has been believed to develop student motivation (Grabe, Grabe, 2007; Kelleher,2000; Osborne, Collins, 2000; Rodrigues et al., 1999;Skinner, 2003).Trimmel and Bachman (2004) examined the effect of presenting laptops into classrooms and one of their findings was that: " information technology has a positive impact on school attendance and learning interest".

ICTs, particularly computers and Internet technologies, facilitate new manners of teaching and learning rather than merely permit educators and learners to perform what they have executed before in a correct way. Learners employing ICTs for learning aims become involved in the process of learning and as more and more learners employ computers as information sources and cognitive means (Jonassen, Reeves,1996), the effect of the technology on aiding how learners learn will go on to grow. Parkinson \&Hollamby,(2003) ; Roweliffe, (2003) discover that PowerPoint motivates students, if it is exploited adequately. Obviously, ICT like videos, television and multimedia computer software can be employed to supply real content that will attract and involve the learners in the learning process.

Becta (2004)categorizes the barriers as falling into two primary kinds: the teacherlevel barriers such as lack of time, lack of confidence and resistance to change, or the school-level barriers such as lack of training and access to resources.

Lack of confidence is considered as one of the obstacles that stop teachers from employing ICT in teaching. In the Becta (2004) survey of practitioners, for instance, the matter of lack of confidence was the field that captivated nearly all answers from those that took part. This simply means that numerous of the respondents to the Becta survey who detected their lack of confidence as an obstacle concentrated on an apprehension of acknowledging to their students that they had restricted familiarity in the domain of ICT. Therefore, teachers who have little or no confidence in applying technologies in their occupation will attempt to escape them altogether (Dawes, 2001; Larner, Timberlake ,1995; Russell, Bradley,1997; Jones, 2004).

Lack of teacher computer competence is another significant obstacle that should be taken into consideration for successful implementation of ICT into teaching. By computer competence, I mean the knowledge and capability to utilize computers and related technology adequately. Jones (2004) announces that instructors competence relate directly to confidence. 
The successful implementation of technologies into teaching relies strongly on teachers' encouragement and attitudes. Mumtaz (2000) states that "teachers' beliefs about teaching and learning with ICT are central to integration". That is to say, if teachers hold positive attitudes concerning the application of technologies they can without difficulty give beneficial vision about the adoption of ICT into teaching.

Lack of time is considered as one of the biggest constraints to the implementation of ICT into the teaching situation. According to Manternach-Wigans et al. (1999), instructors are concerned about the lack of time for technology; they are aware of the fact that they require more time to master computer basics, outline how to apply technology into their lessons, and positively utilize the technology in the classroom.

Lack of effective training is another obstacle against the use of ICT into teaching. Brand (1998) has asserted, "If students are going to be prepared for a technological society, they must be taught by confident and skilled teachers. This can only be done by adequate training and development of teachers" (p. 13). Lack of training is a potential source for educators' low levels of confidence and negative attitudes towards computers (Cox et al., 1988); Kumar, Kumar, 2003).

The adequate use of technology involves the accessibility of equipments. Pelgrum (2001) discovered that the deficient and unsatisfactory number of computers accessible to teachers was one of the mentioned troubles when educators were questioned about barriers to their employment of ICT. Similarly, Mumtaz (2000) confirms that a lack of computers and software can restrict what teachers can do in the classroom concerning the use of ICT in education. David (1994) stresses four essential elements for educators' effective utilization of ICT. These factors were: professional development, access to technology, technical support, and functionality of the technology. Obviously, if ICT resources cannot be accessed by the instructor, then it will not be utilized.

Lack of technical support is another factor that stops schools from successfully delivering excellent and imaginative lessons using ICT. Jones (2004) declares that the breakdown of a computer generates disturbance and if there is lack of technical support, then it is possible that the typical repairs of the computer will not be implemented resulting in teachers not employing computers in teaching.

\section{RESEARCH METHODOLOGY}

In this investigation, the questionnaire is used as data collection tool so as to gather necessary data. Admittedly, the questionnaire is one of the popular instruments utilized in conducting surveys. The population considered for this study is constituted of Moroccan university English language teacher. Indeed, 46 is the number of respondents who participate in this investigation during $2013-2014$ academic year in Morocco. Thirty university English language teachers at Moulay Ismail University Faculty of Arts and Humanities English department - Meknes and 19 university English language teachers at Sidi Mohamed Ben AbdellahDhar - El Mahraz English department- Fes. In this study the questionnaire is utilized as data 
collection instrument so as to find out the obstacles which prevent instructors from implementing technology in their classes. In this regard, it is necessary to state that the questionnaire targets only university English language teachers. Forty-six university English language teachers is the total number of the participants in this examination.

As shown in figure 1, there seems to be a relatively big number of teachers males $65,2 \%$ while females make up $34,8 \%$ of the teachers included in the study.

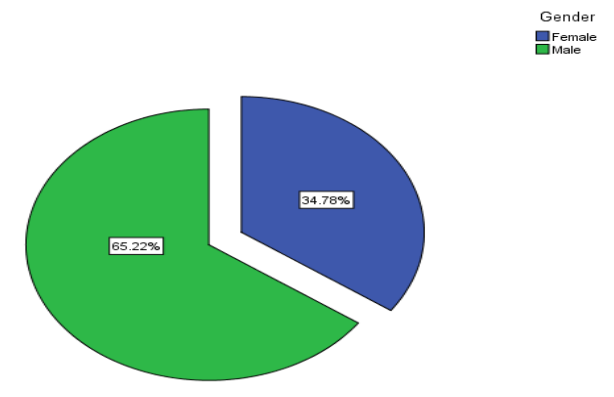

Figure 1. Distribution of Participants by Gender.

Furthermore, the participants in this investigation are experienced since the majority $86,9 \%$ of this population has more than five years of experience in teaching. The results indicate that only $13,1 \%$ of the participant instructors who have five or less than five years of experience. Therefore, it can be emphasized that most of the participants in this examination are quite experienced ( See figure 2).
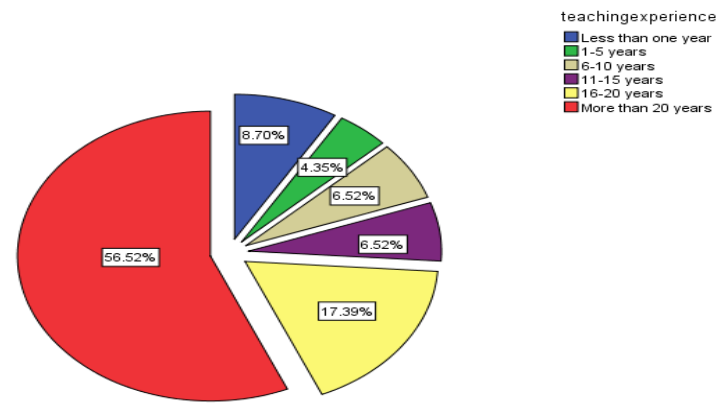

Figure 2. Distribution of Participants by Years of Teaching Experience.

When respondents were asked about computer ownership, all of them (100\%) reported that they possess a personal computer ( See Table 1). 
$\underline{\text { Table 1. Distribution of Participants by computer ownership }}$

\begin{tabular}{|c|c|c|}
\hline Computer Ownership & Frequency & Percent \\
\hline Yes & 46 & 100.0 \\
\hline
\end{tabular}

The results shown in table 2 indicate that the majority of the participants (80.4\%) have been using computers in their classrooms more than ten years. The rest of the participant teachers $19.6 \%$ have been using computers in teaching less than ten years.

Table 2. Distribution of Participants by Computer Use

\begin{tabular}{|l|c|c|}
\hline Using a Computer & Frequency & Percent \\
\hline 1-5 years & $\mathbf{2}$ & $\mathbf{4 . 3}$ \\
6-10 years & $\mathbf{7}$ & $\mathbf{1 5 . 2}$ \\
11-15 years & $\mathbf{1 1}$ & $\mathbf{2 3 . 9}$ \\
16-20 years & $\mathbf{1 8}$ & $\mathbf{3 9 . 1}$ \\
More than 20 years & $\mathbf{8}$ & $\mathbf{1 7 . 4}$ \\
Total & $\mathbf{4 6}$ & $\mathbf{1 0 0 . 0}$ \\
\hline
\end{tabular}

\section{FINDINGS}

The Statistical Package for Social Sciences (SPSS) version 19 is utilized as an important type of data analysis to analyze the data from the survey questionnaire. In fact, 49 copies of the questionnaire are distributed, 46 are returned, resulting in a return rate of $93,8 \%$. Descriptive statistics (frequencies and percentages) are computed as a means of describing the results obtained. This chapter presents the findings of the questionnaire data. The data gathered is utilized to answer the following research questions:

RQ1 : How essential do Moroccan university English language teachers think ICT is in teaching?

RQ2 :What are Moroccan university English language teachers perceived barriers to the integration of ICT in teaching?

\subsection{Findings related to research question 1:}

The first research question "How essential do Moroccan university English language teachers think ICT is in teaching?" is evaluated through eleven items in the questionnaire. Indeed, the first five points in the questionnaire illustrate the 
instructors' impression concerning the importance of hardware types in teaching. The second five items demonstrate the teachers' perceptions regarding the significance of software types in teaching. The last item, the eleventh one, is in the form of an open-ended question in which respondents are invited to add other ICT tools essential in their teaching if any.

Table 3. Response frequencies for the importance of hardware types in teaching

\begin{tabular}{|c|c|c|c|c|c|c|c|c|c|c|}
\hline \multirow[t]{2}{*}{ Hardware } & \multicolumn{2}{|c|}{ Not at all } & \multicolumn{2}{|c|}{ A little } & \multicolumn{2}{|c|}{$\begin{array}{c}\text { To some } \\
\text { extent }\end{array}$} & \multicolumn{2}{|c|}{ Undecided } & \multicolumn{2}{|c|}{$\begin{array}{c}\text { Very } \\
\text { Essential }\end{array}$} \\
\hline & $\mathrm{F}$ & $\%$ & $\mathrm{~F}$ & $\%$ & $\mathrm{~F}$ & $\%$ & $\mathrm{~F}$ & $\%$ & $\mathrm{~F}$ & $\%$ \\
\hline 1. Computers & 1 & 2.2 & 0 & 0 & 8 & 17.4 & 0 & 0 & 37 & 80.4 \\
\hline $\begin{array}{l}\text { 2. CD-ROMs or } \\
\text { DVDs }\end{array}$ & 3 & 6.5 & 6 & 13.1 & 20 & 43.5 & 2 & 4.3 & 15 & 32.6 \\
\hline 3. Data Projector & 3 & 6.5 & 4 & 8.7 & 13 & 28.3 & 1 & 2.2 & 25 & 54.3 \\
\hline $\begin{array}{ll}\text { 4. Interactive } \\
\text { Whiteboards }\end{array}$ & 13 & 28.3 & 5 & 10.9 & 11 & 23.9 & 2 & 4.3 & 15 & 32.6 \\
\hline 5. Printers & 1 & 2.2 & 1 & 2.2 & 12 & 26 & 1 & 2.2 & 31 & 67.4 \\
\hline
\end{tabular}

The first five items in the questionnaire clarify the importance of hardware types in teaching as mentioned before. The results from the table show clearly that the majority of the respondents $97,8 \%$ demonstrate that computers are essential in their teaching. Only $2.2 \%$ of teachers consider computers as not essential in their classes. It is also obvious that $89,2 \%$ of the respondents think that CD-ROMs or DVDs are essential in their lessons. Whereas, only $6,5 \%$ of them who disagree with the statement. $91,3 \%$ is the frequency of instructors who regard data projector as crucial in their teaching; however 6,5\% of them see data projector as not essential. As the table shows, the frequency of the importance of the interactive whiteboards in teaching $67,4 \%$ is considerably lower than the importance of the other hardware types in teaching. It is worth mentioning that the highest frequencies of the importance of hardware types in teaching are observed for computers $(97,8 \%)$ and printers $(95,6 \%)$.

Table 4. Response frequencies for the importance of software types in teaching

\begin{tabular}{|c|c|c|c|c|c|c|c|c|c|c|}
\hline \multirow[t]{2}{*}{ Software } & \multicolumn{2}{|c|}{ Not at all } & \multicolumn{2}{|c|}{ A little } & \multicolumn{2}{|c|}{$\begin{array}{l}\text { To some } \\
\text { extent }\end{array}$} & \multicolumn{2}{|c|}{ Undecided } & \multicolumn{2}{|c|}{$\begin{array}{l}\text { Very } \\
\text { Essential }\end{array}$} \\
\hline & $\mathrm{F}$ & $\%$ & $\mathrm{~F}$ & $\%$ & $\mathrm{~F}$ & $\%$ & $\mathrm{~F}$ & $\%$ & 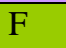 & $\%$ \\
\hline 6. Word processing & 2 & 4.3 & 1 & 2.2 & 4 & 8.7 & 1 & 2.2 & 38 & 82.6 \\
\hline $\begin{array}{ll}\text { 7. } & \begin{array}{l}\text { Presentation } \\
\text { software }\end{array} \\
\end{array}$ & 6 & 13.1 & $\mathbf{0}$ & $\mathbf{0}$ & 7 & 15.2 & 1 & 2.2 & 32 & 69.5 \\
\hline 8. Spreadsheets & 8 & 17.4 & 5 & 10.9 & 19 & 41.3 & 3 & 6.5 & 11 & 23.9 \\
\hline 9. Internet & $\mathbf{0}$ & $\mathbf{0}$ & 1 & 2.2 & 11 & 23.9 & 1 & 2.2 & 33 & 71.7 \\
\hline 10. E-mail & $\mathbf{0}$ & $\mathbf{0}$ & 4 & 8.7 & 9 & 19.6 & 1 & 2.2 & 32 & 69.5 \\
\hline
\end{tabular}

Indonesian Journal of EFL and Linguistics, Vol. 1 (2), 2016 
The second five items in the questionnaire describe the teachers' perception concerning the importance of software types in their teaching. These results indicate that $93,5 \%$ of the respondents do actually view word processing as essential in their lessons; however, 4,3\% do not consider word processing as essential. 84,7\% of the participants think that presentation software is essential in their teaching. 13,1\% of the teachers involved in this examination do not believe that presentation software is crucial in their classes. It is also evident from the results presented in the table that $75,8 \%$ see spreadsheets as fundamental in their teaching. Whereas, $17,4 \%$ of them disagree with the statement. As table 4.2 indicates, the highest frequencies for the importance of software types in teaching were observed for Internet $(97,8 \%)$ and email (97,8\%). Obviously, the conclusion that can be drawn from table 3 and table 4 . is that hardware and software types are essential in the respondents' teaching.

\subsection{Findings related to research question 2:}

The second research question in this work is "What are Moroccan university English language teachers perceived barriers to the integration of ICT in teaching?" Briefly, this investigation also examines the difficulties and obstacles that Moroccan university English language teachers face while employing ICT in their teaching. Another way of expressing this point is that the integration of ICT into teaching is a complicated process and instructors might encounter numerous barriers. For this reason, examining the obstacles to the use of ICT in education may assist educators to succeed in dealing with these problems. As noted in the literature review, there are various types of the barriers that have been used by several researchers to classify barriers to instructor use of ICT in teaching. Ertmer (1999), for instance, categorizes the barriers into two main classes: first order barriers which include difficulties regarding training, time, equipment and support and second order barriers which embrace teachers' belief, visions concerning technology integration. In the same line, Becta (2004) shows another classification of barriers whether these obstacles connected to teacher-level barriers like lack of time, lack of confidence and lack of resistance to change, or the school-level barriers like lack of training and access to resources. In this regard, it is essential to declare that this study focuses on the second classification of barriers, Becta's categorization of barriers, in order to introduce the obstacles that teachers and schools face.

Obviously, the second research question "What are Moroccan university English language teachers perceived barriers to the integration of ICT in teaching?" is measured through fifteen items in the questionnaire. The first six items deal with factors associated with teachers' adoption of ICT. Factors associated with schools' adoption of ICT in teaching are evaluated through eight items in the questionnaire. 
Table 5. Response frequencies for factors associated with teachers' adoption of ICT

\begin{tabular}{|c|c|c|c|c|c|c|c|c|c|c|}
\hline & \multicolumn{2}{|c|}{$\begin{array}{l}\text { Strongly } \\
\text { disagree }\end{array}$} & \multicolumn{2}{|c|}{ Disagree } & \multicolumn{2}{|c|}{ Undecided } & \multicolumn{2}{|c|}{ Agree } & \multicolumn{2}{|c|}{$\begin{array}{l}\text { Strongly } \\
\text { agree }\end{array}$} \\
\hline & $\mathrm{F}$ & $\%$ & $\mathrm{~F}$ & $\%$ & $\mathrm{~F}$ & $\%$ & $F$ & $\%$ & $F$ & $\%$ \\
\hline 12. Lack of competence & 25 & 54.3 & 12 & 26.1 & $\mathbf{0}$ & $\mathbf{0}$ & 6 & 13.1 & 3 & 6.5 \\
\hline $\begin{array}{l}\text { 13. Fear of computer } \\
\text { equipment breaking } \\
\text { down in the lesson }\end{array}$ & 28 & 60.9 & 10 & 21.7 & $\mathbf{0}$ & $\mathbf{0}$ & 7 & 15.2 & 1 & 2.2 \\
\hline $\begin{array}{l}\text { 14. Belief that traditional } \\
\text { way is better }\end{array}$ & 27 & 58.7 & 11 & 23.9 & $\mathbf{0}$ & $\mathbf{0}$ & 7 & 15.2 & 1 & 2.2 \\
\hline 15. Lack of confidence & 27 & 58.7 & 13 & 28.3 & $\mathbf{0}$ & $\mathbf{0}$ & 3 & 6.5 & 3 & 6.5 \\
\hline $\begin{array}{l}\text { 16. Colleagues' negative } \\
\text { views about } \\
\text { technology }\end{array}$ & 28 & 60.9 & 16 & 34.8 & $\mathbf{0}$ & $\mathbf{0}$ & 2 & 4.3 & $\mathbf{0}$ & $\mathbf{0}$ \\
\hline $\begin{array}{l}\text { 17. Lack of time during } \\
\text { the lesson }\end{array}$ & 17 & 36.9 & 14 & 30.4 & $\mathbf{0}$ & $\mathbf{0}$ & 6 & 13.1 & 9 & 19.6 \\
\hline
\end{tabular}

The results from the above table show clearly that the majority of the respondents $80,4 \%$ strongly disagreeing or disagreeing with the idea that lack competence stops them from using ICT in their lessons. $19,6 \%$ believe that lack of competence really prevents them from using ICT in their lessons. Also, 82,6\% of the participants do not consider fear of computer equipment breaking down in the lesson as an obstacle discouraging them from using ICT in their lessons; however, 17,4\% of them view fear of computer equipment breaking down in the lesson as a key barrier preventing them from employing ICT in their teaching. Similarly, 82,6\% of the participant teachers do not see the belief that traditional way is better preventing them from utilizing ICT in their lessons; however, 17,4\% of them agree with the statement. The highest frequencies of strongly disagreeing or disagreeing are observed for lack of confidence $87 \%$ and colleagues' negative views about technology 95,7\%.

Concerning lack of time during the lesson, $67,3 \%$ of the teachers involved in the study strongly disagreeing or disagreeing with the fact that lack of time during the lesson hinders them from making use of ICT in their classes.

Table 6. Response frequencies for factors associated with schools' adoption of ICT

\begin{tabular}{|c|c|c|c|c|c|c|c|c|c|c|}
\hline & \multicolumn{2}{|c|}{$\begin{array}{l}\text { Strongly } \\
\text { disagree }\end{array}$} & \multicolumn{2}{|c|}{ Disagree } & \multicolumn{2}{|c|}{ Undecided } & \multicolumn{2}{|c|}{ Agree } & \multicolumn{2}{|c|}{$\begin{array}{l}\text { Strongly } \\
\text { agree }\end{array}$} \\
\hline & $\mathrm{F}$ & $\%$ & $\mathrm{~F}$ & $\%$ & $\mathrm{~F}$ & $\%$ & $\mathrm{~F}$ & $\%$ & $\mathrm{~F}$ & $\%$ \\
\hline 18. Large classes & 7 & 15.2 & 7 & 15.2 & 0 & 0 & 11 & 23.9 & 21 & 45.7 \\
\hline 19. Insufficient space & 16 & 34.8 & 13 & 28.3 & $\mathbf{0}$ & $\mathbf{0}$ & 7 & 15.2 & 10 & 21.7 \\
\hline 20. Lack of computers & 2 & 4.3 & 7 & 15.2 & 0 & 0 & 11 & 23.9 & 26 & 56.6 \\
\hline 21. Lack of Internet & 1 & 2.2 & 7 & 15.2 & $\mathbf{0}$ & $\mathbf{0}$ & 14 & 30.4 & 24 & 52.2 \\
\hline 22. Lack of training & 20 & 43.5 & 13 & 28.2 & $\mathbf{0}$ & $\mathbf{0}$ & 7 & 15.2 & 6 & 13.1 \\
\hline $\begin{array}{l}\text { 23. A little access to } \\
\text { ICT }\end{array}$ & 15 & 32.6 & 14 & 30.5 & $\mathbf{0}$ & $\mathbf{0}$ & 10 & 21.7 & 7 & 15.2 \\
\hline 24. Insufficient & 7 & 15.2 & 8 & 17.4 & 0 & 0 & 18 & 39.1 & 13 & 28.3 \\
\hline
\end{tabular}

Indonesian Journal of EFL and Linguistics, Vol. 1 (2), 2016 


\begin{tabular}{|c|c|c|c|c|c|c|c|c|c|c|}
\hline technical support & & & & & & & & & & \\
\hline $\begin{array}{l}\text { 25. Insufficient time to } \\
\text { acquire ICT skills }\end{array}$ & $\mathbf{1 9}$ & $\mathbf{4 1 . 3}$ & $\mathbf{1 7}$ & $\mathbf{3 7}$ & $\mathbf{0}$ & $\mathbf{0}$ & $\mathbf{8}$ & $\mathbf{1 7 . 4}$ & $\mathbf{2}$ & $\mathbf{4 . 3}$ \\
\hline
\end{tabular}

The obstacles associated with schools' adoption of ICT in teaching are evaluated through eight items in the questionnaire. From the results shown in the table above, it is possible to observe a big difference in the participants responses $30,4 \%$ strongly disagreeing or disagreeing and $69,6 \%$ agreeing or strongly agreeing on the idea that large classes discourage them from using ICT in the classroom. Besides, 63,1\% of the respondents strongly disagreeing or disagreeing that insufficient space stop them from making use of ICT in their lessons. Whereas, only 36,9\% of them agree with the statement. The highest frequencies of agreeing or strongly agreeing are noticed for lack of computers $80,5 \%$ and lack of Internet $82,6 \%$. That is to say, the respondents do really regard lack of Internet and lack of computers as crucial barriers preventing them from integrating ICT in the schools where they work. As to lack of training, $28,3 \%$ of the participant teachers who affirm that lack training discourages them from making use of ICT in their lessons. In fact, the majority of the participants $71,7 \%$ disagree with the statement. It is evident that table 3.4 makes clear the idea that $63,1 \%$ of the respondents demonstrate that a little access to ICT does not stop them from implementing ICT in their classes; however, 36,9\% of them see a little access to ICT as a key obstacle. As it is also indicated in table 3.4, $32,6 \%$ of the respondents strongly disagree or disagree with the statement which states that insufficient technical support discourages teachers from using ICT in their lessons. Besides, the majority of the participant teachers $78,3 \%$ strongly disagree or disagree with the idea that insufficient time to acquire ICT skills prevent them from integrating ICT in their lessons. While $21,7 \%$ strongly agree or agree with the statement.

In the fifteenth item the respondent are asked if there are additional obstacles preventing them from implementing ICT tools in their lessons and mention them. Actually, no additional barriers are stated.

Certainly, the conclusion that can be drawn from these results is that most of respondents report that large classes, lack of computers, lack of Internet and insufficient technical support are real barriers that prevent them from using ICT in their classes.

\section{CONCLUSIONS AND IMPLICATIONS}

Moroccan university English language teachers view information and communication technology tools as very essential in their teaching practices. Indeed, instructors are aware of the fact that by using hardware and software types in their classrooms they can add a variety to their lessons. Also, by making use of ICT they can afford the students with more individualized learning experience which has a hand in autonomous learning. In summary, it can be said that the importance of information and communication technology in teaching has been identified, but what is missing is the effective integration of materials into teaching. 
It is obvious that Information and communication technology plays a crucial role in the field of education. Bottino (2003) and Sharma (2003) confirm that the use of ICT can enhance performance, teaching, administration, and develop relevant skills in undeveloped societies. ICT is an effective tool for providing new educational opportunities. Actually, by integrating technology in education, teachers would get their learners ready for lifelong learning. The main purpose of this study is to obtain satisfactory understanding of how important do Moroccan university English language teachers think ICT is in their teaching.

Based on the statistical analysis of the survey data, the conclusions that can be drawn from this investigation are the following:

Moroccan university English language teachers view information and communication technology tools as very essential in their teaching practices. Indeed, instructors are aware of the fact that by using hardware and software types in their classrooms they can add a variety to their lessons. Also, by making use of ICT they can afford the students with more individualized learning experience which has a hand in autonomous learning. In summary, it can be said that the importance of information and communication technology in teaching has been identified, but what is missing is the effective integration of materials into teaching.

This investigation comes to the conclusion that Moroccan university English language teachers are familiar with the importance of ICT in their classrooms. However, this does not guarantee a successful integration of technology in teaching. ICT as a teaching aid is more complicated in that it requires more specific skills from the teacher. This study indicates clearly that teachers are confronted with numerous obstacles that stop them from making use of technology in their lessons. Furthermore, large classes, lack of computers, lack of Internet and insufficient technical support are the most essential barriers discouraging teachers from integrating technology in their teaching practices.

It is possible to say that this work does provide a good picture of the views of teachers to the essential barriers for ICT integration in their schools. The results of this investigation also show crucial suggestions that do play a role in the successful implementation of ICT in teaching. That is, in order to integrate information and communication technology in Moroccan universities, teachers propose availability of training, availability of ICT resources and effective school policy.

The implementation of information and communication technology is a complicated process that requires more specific skills from the instructors. Besides, some barriers may stop teachers from integrating ICT in their lessons. Certainly, the main objective of this investigation is to find out the barriers that stop Moroccan university English language teachers from using technology in their teaching practices. Admittedly, this study is guided by two primary research questions:

RQ: How essential do Moroccan university English language teachers think ICT is in teaching? 
RQ: What are Moroccan university English language teachers perceived barriers to the integration of ICT in teaching?

This investigation comes to the conclusion that Moroccan university English language teachers are confronted with numerous obstacles that stop them from making use of technology in their lessons. Furthermore, large classes, lack of computers, lack of Internet and insufficient technical support are the most essential barriers discouraging teachers from integrating technology in their teaching practices. This work suggests that the effective integration of information and communication technology in teaching is impeded by several distinctive constraining factors. Based on the findings of the present study, a number of implications related to ICT integration in the Moroccan universities English departments can be drawn from this piece of research. These can be summed up as follows:

1. Provide teachers with the necessary ICT tools, (hardware and software), and good network connection.

2. The classroom design should be appropriate to make a good use of ICT equipments.

3. Teachers' worries and misunderstandings about the implementation of ICT tools into the language teaching material should be minimized.

4. Encourage faculties to develop their ICT integration policies.

5. The government and its education department should provide the encouragement and support that enables teachers to integrate ICT in their lessons.

6. The institution must provide a proper evaluation on integration of ICT tools in teaching.

\section{References}

Al-Ansari, H. (2006). Internet use by the faculty members of Kuwait University.The Electronic Library Vol.24, No. (6), Pp; 791-803.

Andrews, R. (2000). Learning, Literacy and ICT: What's the connection? English in Education,34 (3), 3-18.

Attwell, P; Battle, J. (1999).“Home Computers and School Performance”.The Information Society. No. (15), Pp. 1-10.

Becker, H. J. (2000). "Pedagogical Motivations for Student Computer Use that Leads to Student Engagement".Education Technology. Vol. 40, No. 5, Pp; 517.

Becta.(2004). A review of the research literature on barriers to the uptake of ICT by teachers. $\quad$ Retrieved April 17, 2014, from http://partners.becta.org.uk/page_documents/research/barriers.pdf.

Blanskat, A., Blamire, R., \&Keflala, S. (2006). A review of studies of ICT impact on schools in Europe.European Schoolnet. 
Bottino, R. M. (2003),'ICT, national policies, and impact on schools and teachers' development' 'CRPIT '03: Proceedings of the 3.1 and 3.3 working groups conference on International federation for information processing', Australian Computer Society, Inc., Darlinghurst, Australia, Australia, 3-6.

Brand, G. (1998). What research says: Training teachers for using technology.Journal of Staff Development, 19(1), 10-13.

Bransford, J., Brown, A. L., \& Cocking, R. R. (Eds). (2000). How people learn: Brain, mind, experience, and school (2nd ed.). Washington, D.C: National Academy Press.

Cox, M., Rhodes, V., \& Hall, J. (1988). The use of computer-assisted learning in primary schools: Some factors affecting the uptake. Computers and Education, 173-178.

David, J.L. (1994). Realizing the promise of technology: Policy perspective.In B. Means (Ed.), Technology and Education Reform. (P. 169-189). San Francisco: Jossey-Bass Publishers.

Dawes, L. (2001). What stops teachers using new technology. In M. Leask (Ed.), Issues in Teaching using ICT (pp. 61-79).London: Routledge.

Ertmer, P. A. (1999). Addressing First- and Second-Order Barriers to Change:Strategies for Technology Integration. Educational Technology Research and Development, 47(4), 47-61.

Grabe, M., \&Grabe, C. (2007).Integrating technology for meaningful learning (5th ed). Boston, MA: Houghton Mifflin.

Harris, S. (2002). Innovative pedagogical practices using ICT in schools in England.Journal of Computer Assisted Learning, No. 18, Pp;449-458.

Iding, M., Crosby, M. E., \&Speitel, T. (2002). Teachers and technology: Beliefs and practices. International Journal of Instructional Media, 29(2), 153-171.

Jonassen, D. H., Peck, K. L., \& Wilson, B. G. (1999). Learning with technology: A constructivist perspective. Upper Saddle River, NJ: Merrill.

Jonassen, D. \& Reeves, T. (1996). Learning with technology: Using computers as cognitive tools. In D. Jonassen (Ed.), Handbook of Research Educational on Educational Communications and Technology (pp 693-719). New York: Macmillan.

Jones, A. (2004). A review of the research literature on barriers to the uptake of ICT by teachers: British Educational Communications and Technology Agency (Becta).

Kelleher, P. (2000). A review of recent developments in the use of information communication technologies (ICT) in science classrooms.Australian Science Teachers Journal, 46(1), 33-38.

Kumar, P., \& Kumar, A. (2003).Effects of web-based projects on pre-service and in service teachers' attitudes towards computers and their technology skills.Journal of Computing in Teacher Education, 19, 87-92.

Larner, D., Timberlake L. (1995). Teachers with limited computer knowledge: variables affecting use and hints to increase use. The Curry School of Education, University of Virginia. 
Lau BT and Sim CH (2008).Exploring the extent of ICT adoption among secondary school teachers in Malaysia.International Journal of Computing and IT Research, Vol. 2 (2) 19-36

Lever-Duffy, J. McDonald, J. B. and Mizell A. P. (2005) Teaching and learning with technology. 2nd ed. San Francisco: Pearson.

Lim, C. P. \& Chai, C.S. (2004), An activity-theoretical approach to research of ICT integration in Singapore schools: Orienting activities and learner autonomy', Computers \& Education Vol. 43, No. (3), Pp; 215--236.

Manternach-Wigans, L., Bender, C., L. \&Maushak, N. J. (1999) Technology integration in Iowa high schools: perceptions of teachers and students.College of Education, Iowa State University.

Mumtaz, S. (2000). Factors affecting teachers' use of information and communications technology: a review of the literature. Journal of Information Technology for Teacher Education, 9(3), pp.319-341.

Osborne, J., \& Collins, S. (2000). Pupils' and parents' views of the school science curriculum. London, UK: King's College London.

Parkinson, J., \&Hollamby, P. (2003). PowerPoint: Just another slide show or a useful learning aid? School Science Review, 48(309), 61-68.

Pelgrum, W. J. (2001). Obstacles to the integration of ICT in education: results from a worldwide educational assessment. Computers and Education, 37 pp.163178.

Plomp, T.; Pelgrum, W. J. \& Law, N. (2007), 'SITES2006-International comparative survey of pedagogical practices and ICT in education', Education and Information Technologies Vol.12, No. (2), Pp; 83-92.

Rodrigues, S., Chittleborough, G., Gooding, A., Papadimitropoulos, T., Varughese, V. K., Kemp, ...Helme, S. (1999). Using CD-ROMs in teaching science: Findings from a small scale study.Australian Journal of Educational Technology, 15(2), 136-147.

Romeo, G. (2006). Engage, empower, enable: Developing a shared vision for technology in education. In D. Hung \& M. S. Khine (Eds), Engaged learning with emerging technologies (pp. 149-175). Dordrecht, the Netherlands: Springer.

Rowcliffe, S. (2003).Using PowerPoint effectively in science education: Lessons from research and guidance for the classroom. School Science Review, 84(309), 69-75.

Russell, G., Bradley, G. (1997). Teachers' computer anxiety: implications for professional development. Education and Information Technologies, 2(1), pp.17-30.

Sharma, R. (2003), 'Barriers in Using Technology for Education in Developing Countries', IEEE0-7803-7724-9103.Singapore schools', Computers \&EducationVol .41, No.(1),Pp; 49--63.

Shamatha, J. H., Peressini, D., \&Meymaris, K. (2004).Technology-supported mathematics activities situated within an effective learning environment theoretical framework. Contemporary Issues in Technology and Teacher Education, 3(4), 362-381. 
Skinner, N. C., \&Preece, P. F. W. (2003). The use of information and communications technology to support the teaching of science in primary schools.International Journal of Science Education, 25(2), 205-219.

Trimmel, M. and Bachman, J. (2004) Cognitive, social, motivational and health aspects of students in laptop classrooms.Journal of Computer AssistedLearning. 20. 151-158.

Wheeler, S. (2001). Information and communication technologies and the changing role of the teacher.Journal of Educational Media, Vol. 26, No.(1), Pp;7-17.

Wozney, L., Venkatesh, V., \&Abrami, P. C. (2006).Implementing computer technologies: Teachers' perceptions and practices.Journal of Technology and Teacher Education, 14(1), 173-207.

Yuen, A.; Law, N. \& Wong, K. (2003), 'ICT implementation and school leadership Case studies of ICT integration in teaching and learning', Journal of Educational Administration Vol. 41 No. 2, Pp;158-170

Zhang, P., \& Aikman, S. (2007). Attitudes in ICT Acceptance and use. In J. Jacko (Ed.), Human-Computer Interaction, Part I (pp. 1021-1030). Syracuse, NY: Springer-Verlag Berlin Heidelberg. 